\title{
The Policies on Civic Education in Developing National Character in Indonesia
}

\author{
Encep Syarief Nurdin ${ }^{1}$ \\ ${ }^{1}$ General Education Program, School of Postgraduate, Universitas Pendidikan Indonesia, Indonesia \\ Correspondence: Encep Syarief Nurdin, General Education, Program of Civic Education, Faculty of Social \\ Science Education, Universitas Pendidikan Indonesia, Indonesia. E-mail: encepsynur15@gmail.com
}

Received: January 30, 2015 Accepted: June13, 2015 Online Published: July 30, 2015

doi:10.5539/ies.v8n8p199 URL: http://dx.doi.org/10.5539/ies.v8n8p199

\begin{abstract}
Each country has different policies on the implementation of Civic Education. As an independent country, Indonesia administers Civic Education separately through a special subject under the name 'citizenship education', while other countries, such as Malaysia, integrate this form of education into other subjects. The policies on Civic Education in Indonesia aim to mould a citizen who has the spirit of nationalism and patriotism (Explanation of Article 37 of the Law No. 20 of 2003). The research was conducted using library research. Meanwhile, data were analyzed descriptively, consisting of quotes. In addition, Civic Education as value-based education stresses on the realization of a good citizen, who is has holistic competencies in knowledge, skills, and traits based on the national character (the values of Pancasila or the Five Principles of Indonesia).
\end{abstract}

Keywords: citizenship education, civic education, character education, national identity, Pancasila

\section{Introduction}

\subsection{Background}

The policy on the implementation of Civic Education in Indonesia is not something new, as can be identified from various legal products explaining the enactment of Civic Education in various versions and names. Nevertheless, the process of establishing the epistemology of Civic Education as a new discipline of science was only recently found in the preliminary work of Somantri titled "Menggagas Pembaharuan Pendidikan IPS" [Initiating Reforms in Social Sciences] (2001) and Winataputra's dissertation titled "Jatidiri Pendidikan Kewarganegaraan sebagai Wahana Sistemik Pendidikan Demokrasi" [The Identity of Civic Education as a Systemic Medium of Democratic Education] (2001) (Sapriya, 2007, p. 619). Hence, Civic Education in Indonesia is still posed with challenges which include:Civic Education as a field of academic study still requires epistemological development and academic communities in order for its position to be increasingly sturdy and steady; Civic Education needs the support from academic communities in order to consolidate its body of knowledge, so that its existence as an educational discipline will be more reliable and trustworthy; and Conceptual-philosophical studies to strengthen and develop the structure and body of Civic Education as an educational discipline means development at the level of scientific foundation (Sapriya, 2007, p. 621).

In an attempt of consolidating the existence of Civic Education, the government has issued policies on the implementation of Civic Education in schools and higher education institutions. Systematically, the formal-juridical foundations of Civic Education in Indonesia are Law No. 20 of 2003 on National Education System as the operational foundation, Ministry's Regulation No. 22 of 2006 on Content Standards and no. 23 of 2006 on Graduate Competence Standards as curricular foundation (Sabarudin, 2010, p. 66), and the most recent is Law No. 12 of 2012. In article 37, paragraph (1) of Law No. 20 of 2003, it is stated that the curriculum of primary and secondary education must contain “... b. Civic Education," and in paragraph (2) it is stated that education curriculum must contain: ... b. Civic Education ...". Meanwhile, it is explained, "Civic Education shall be intended to mould learner to become a human being who has a sense of nationalism and patriotism". In the context of social, state, and national life, the life of students in the school is basically a process of social life education in preparing them as citizens (Somantri, 2001; Winataputra, 2001).

However, even though the policies on Civic Education have been implemented in formal institutions, such as schools and higher education institutions, moral crisis never ceases to ravage in Indonesia. According to Azra 
(2001), there are at least seven primary problems encountered by the education of Indonesia, which are the roots of crisis of morality and morals, namely (1) the orientation of education has lost its objectivity; (2) self-maturity does not occur appropriately in the school environment; (3) education process in school severely restricts the space for creativity both for students and teachers; (4) the load of the curriculum is too burdensome and tends to be oriented at developing cognitive domain only; (5) even if there are content materials cultivating affection, such as religious education and moral education, or what is now familiarly termed Civic Education; (6) at the same time, students are posed with contradictory set of values; and (7) a small number of living moral exemplary for students in their lives.

Hence, implementative reinforcement is needed in encouraging national character and providing facilities of national character through education. The moral crisis, if not immediately addressed, will trigger the development of characters which do not reflect national identity and character, something which can eventually lead to (1) disorientation and the inability to appreciate the values of Pancasila (the five principles of Indonesia)as national philosophy and ideology; (2) limited integrated policy tools in realizing the essential values of Pancasila; (3) the shift in the ethics of national and state life; (4) the diminishing awareness of national cultural values; (5) the threat of national disintegration; and (6) the weakening national independence. This is in line with the views of DeRoche, Sullivan, and Garret (1999) who state that:

Our young need character education to learn and practice those values inherent in this nation's founding documents. Schools need character education to become places where students construct their socio-moral selves; where they learn to reason critically and morally; and where they practice the habits and skills of being good people and good citizens.

Civic education through implementative policy restructuration and consolidation, both formal-juridical (Law No. 20 of 2003 and Law No. 12 of 2012) and curricular (Curriculum 2013), are expected to be able to help in re-structuring national character and identity. In the previous research by Rohayani in 2010, it was mentioned that schools have strategic roles in value education; on the other hand, reality shows that they cannot do it alone. The contribution of the teaching and learning process of Civic Education was significant, both directly and indirectly, to the character of young citizens for as much as 19\% (Rohayani, 2010, pp. 2-3). The finding is in accordance with the Grand Design of Character Development (2010, p. 29), that one of the strategies of national character development is education. In addition, McDonell and Russell (1999) are of the view that, "it is in schools that we have the greatest potential for overcoming the crisis of character that is raging all around us". However, is it true that the policies on Civic Education implemented in schools and higher education institutions can develop Indonesia's national character.

\section{Method}

This study was conducted through library research. Previous documents were analysed to established the condition of civic education in Indonesia. The researcher focused more on the civic education policy has tried to shape national character and identity. Documents relevant to the study were critically identified including: constitution Acts, Articles, Chapters among others.

Secondary data was collected by identifying the relevant books, papers or articles, magazines, journals and or other related information. The steps taken involved: general identification of the appropriate source, specific identification of the more specific and most relevant literature and finally, reading and sorting the most relevant literature. This help the researcher to establish the most appropriate and important literature for the study.

The data was interpreted and analyzed descriptively, the process involved excerpts and processing the data to provide an overview about the way policies have been created with the intention of facilitating national character formation or building. Content analysis was also conducted (Suryabrata, 1983, p. 94) to establish the appropriatedness nature of the content. In qualitative research, content analysis focuses on consistency of the findings.

\section{Results}

In Indonesia, civic education as one of the subjects taught in schoolshas undergone many changes both in contentand substance, right from the mid 1970. Records show that in 1975, the curriculum for all levels was put on monitoring and improvement until 1984. The replacement of subjects such as citizenship educationled to the introduction Pancasila Moral Education which contained materials that taught based on experience and practice of Pancasila principles, taught based on practice and memorization guide.

The changes were meant to accommodate the educational mission mandated by Resolution No. II MPR/MPR/1978, on practice and memorization of Pancasila. The constitution Article 39 of the Republic of 
Indonesia Number 2 of 1989 on National Education System, it is outlined that Pancasila and Civic Education have are compulsory components of the curriculum for all levels of education. It is such, a constitutional policy which led to citizenship education. Currently, civic education is seen as a subject that focuses on the development of citizens into people who understand and are able to perform their duties and obligations well as mandated by Pancasila guide and the 1945 Constitution (the regulation No. 22 year 2006 about Standard Content).

Since its establishment, civic education has had several names based on Indonesia's political development. The term civic and civic education have emerged to form the present concepts: "citizenship" (coined in 1957), which discuses how to gain and lose national identity; civics (coined in 1962) discuses more about the history of the national revival in regard to the 1945 Constitution, the state's political speeches, especially geared toward "a nation and character building" of Indonesia; citizenship education (coined in 1968). However, in 1975 civic education changed to Pancasila Moral Education starting from primary school to senior high school, and Pancasila education and nationalism education for college students. In 1994, it was renamed Pancasila and citizenship, and finally according to Law No. 20 of 2003 the concept changed to citizenship education for all levels including at university.

Indonesia's education policy based on Law Number 20 of 2003 suggests that citizenship education should consider: (1) personnel and religious life, faith and piety in all aspects of life; (2) political literacy, law-understanding; (3) human being and democratic life; (4) human and individual intelligence, peace and prosperity; (5) human being and spirit of nationalism, national identity, patriotism and defense for the State; and (6) living in harmony.

The terms used, the content selected and organized, and the strategies of teaching and learning employed in the subject of Civics or Civic Education or Pancasila Moral Education or Pancasila and Civic Education have had fluctuating development for almost four decades (1962-1998), showing the unsteadiness of the framework of thought, as well as demonstrating that conceptual crisis has taken place, thereby impacting on crisis in curricular operations. The unsteadiness can be observed in: Civics in 1962 that was in the form of political indoctrination, Civics in 1968 as the element of Citizenship Education that had the nuance of social sciences; Civic Education in 1969 that was in the form of the teaching of constitution and Temporary People's Consultative Assembly's provisions; Civic Education in 1973 that was identical with the teaching of Social Sciences; Pancasila Moral Education in 1975 and 1984 that came to replace Civic Education with the content of the Guidelines for Instilling and Implementing Pancasila (P4); and Pancasila and Civic Education in 1994 that was the combination of learning materials of Pancasila Education and Civic Education in the form of the teaching of concepts of values synthesized from Pancasila and the P4. The operational crisis is reflected in the changes in content and textbook format, teachers' development that is not articulate, and phenomena in the classroom that have not much shifted from the emphasis on cognitive process of memorizing facts and concepts from the explanation above seem all that happened because the school still treated as a socio-cultural institution, and yet still effective implementation of the learning method conceptually, because there is a paradigm of the Civic Education steadily nationally accepted and used as a reference and operational patterns. Below are the bases of implementing Civic Education in Indonesia.

From the above explanations, it is clear that all of the phenomena were a consequence of the continued treatment of schools associo-cultural institutions and the ineffectiveness of the implementation of learning methods conceptually, as there had been no paradigm of Civic Education that had been accepted and used steadily at the national scope as references and operational patterns. Belo are the foundations of the implementation of Civic Education in Indonesia.

\subsection{Historical Basis}

Historically, the values contained in each principle of Pancasila have long been practiced by the people of Indonesia even before the values were formulated and legitimated. Hence, the values of Pancasila are none other than the national cultures of Indonesia, or in other words, Indonesia as a nation is the causa-materialist of Pancasila. Therefore, based on the historical objective facts, the life of Indonesia as a nation has been inseparable from the values of Pancasila. Consequently, historically Pancasila in its position as the philosophical foundation of the state and ideology of the nation and state, is not an ideology that dominates the nation; instead, the values of each principle of Pancasila are inherent in and originally from Indonesia.

\subsection{Philosophical Basis}

In the ideal situation, the values of Pancasila are the philosophical foundations of the state. Consequently, each aspect of the state administration should be based on the values of Pancasila, including the system of regulations 
and law in Indonesia. Therefore, in state realization, including today's reform era, it is a must that Pancasila become the source of values in the state administration, both in national development (including national character development) in the fields of economy, politics, law, socio-cultural, and defense and security.

\subsection{Conceptual Basis}

Essentially, Pancasila reflects the values of equality, harmony, unity, kinship, togetherness, and wisdom in developing national life. Conceptually, Civic Education is a field of study that is multifaceted with multidisciplinary contexts. It is from the object of studies that the concept of Civics has developed, which literally is taken from the Latin word civicus, meaning citizen in the era of Ancient Greek. The word was later on academically acknolwedged as the embryo of civic education. In Indonesia, it was adapted into "Pendidikan Kewarganegaraan" or shortened into PKn.

\subsection{Formal-Juridical Basis}

Formal-juridical basis, the foundations of civic education in Indonesia are the 1945 Constitution of the Republic of Indonesia as constitutional foundation; Law No. 20 of 2003 concerning National Education System as operational foundation; Law of the Republic of Indonesia No. 12 of 2012 (for Higher Education Institutions) and Regulation of the Minister of National Education No. 22 of 2006 concerning Content Standards, and Regulation of the Minister of National Education No. 23 of 2006 concerning Graduate Standard Competency as curricular foundations. In line with the policies of Ministry of National Education through its Department of National Education Standard, the curriculum of Civic Education for formal education institutions is implemented by referencing the School-Based Curriculum.

The 1945 Constitution as the constitutional foundation, in its fourth paragraph, states the rationales for national goals. One of the goals is as contained in the statement of "educating the national life". Further analyzed, the statement contains quite deep meanings. Educating the national life bears the message of the significance of education for all people. In civic life, this statement conveys a message for the state administrators and the whole people in order to have the abilities of thinking, taking attitudes, and behaving intelligently both in problem solving and decision making related to the state, national, and social life.

The Law of the Republic of Indonesia No. 20 of 2003 concerning National Education System as the operational foundation contains the message related to Civic Education. In Article 3 Paragraph (2) on the functions and goals of the nation, it is revealed that:

The National Education functions to develop the capability, character, and civilization of the nation in an attempt of enhancing its intellectual capacity, and is aimed at developing learners' potentials so that they become persons imbued with human values, who are faithful and pious to one and only God; who possess morals and noble character; who are healthy, knowledgeable, competent, creative, independent; and as citizens, are democratic and responsible.

The provision of Civic Education in the Law of National Education System as a compulsory subject for the primary and secondary schools and Law of the Republic of Indonesia No. 12 of 2012 concerning Higher Education Institutions for Civic Education in higher education institutions all demonstrate that Civic Education subject and course occupies a strategic position in meeting the goals of national education of this country. As for the direction of its development, it should be focused on developing students to be Indonesian people who have the pride and love for the motherland.

\subsection{Curricular Basis}

The enactment of the Law of the Republic of Indonesia No. 20 of 2003 concerning National Education System has triggered quite significant impact on the change of curriculum system in Indonesia. One of the implications is the issuance of Government's Regulation No. 19 of 2005 concerning National Standards of Education. The Government's Regulation stipulates the minimum criteria for education system in the whole territories under the jurisdiction of the Republic of Indonesia. According to Article 35 of Law No. 20 of 2003, National Educational Standards are used as guidelines for the development of curriculum, development of educational personnel, and provisions of facilities and equipment, management, and funding. Thus, the standards have given implications in the implementation of a number of educational standards.

Furthermore, in Article 2, paragraph (1) of the Government's Regulation No. 19 of 2005 concerning National Educational Standards, it is stipulated that the national standards cover the scopes of: (1) Content standards; (2) Process standards; (3) Graduate competency standards; (4) Educator and educational personnel standards; (5) Facilities standards; (6) Management standards; (7) Funding standards; and (8) Educational assessment standards. The implications of this provision are the issuances of Regulation of Ministry of National Education No. 22 
concerning Content Standards and no. 23 of 2006 on Graduate Competency Standards. The minister's regulation is what has been made the operational foundation (reference) for each educational unit in developing the curriculum implemented in the institution.

Based on the Regulation of the Minister of National Education No. 22 of 2006 concerning Content Standards for Primary and Secondary Education, the subject of Civic Education is one focusing on the molding citizens who understand and are able to fulfill their rights and obligations to be Indonesian citizens who are intelligent, skilled, and with character as mandated by Pancasila and the 1945 Constitution. The subject of Civic Education intends to develop students to have the abilities of (1) Thinking critically, rationally, and creatively in coping with civic issues; (2) Participating actively and responsibly, and acting intelligently in social, national, and state activities, as well as in corruption eradication; (3) Developing positively and democratically to shape themselves based on the characters of Indonesian people to be able to live side by side with other nations; and (4) Interacting with other nations in the international stage, whether directly or indirectly, by taking advantage of information and communication technology.

In a discussion held by Civic Education Research Project Team on civic books used in primary, junior secondary, and senior secondary schools, it is apparent that civic is equated to: (a) The Constitution (Senior Secondary School Curriculum, 1968), (b) Pancasila (Senior Secondary School Curriculum, 1968), (c) History of National Resurrection, History of Independence Struggle, the Constitution, and Pancasila (Junior Secondary School Curriculum 1968, Civic Book for Junior Secondary School), and (d) Ethics, History (textbooks for primary school). Furthermore, in the Curriculum 1975, the term Pendidikan Kewargaan Negara/Citizenship Education was changed into Pendidikan Moral Pancasila/PMP (Pancasila Moral Education), containing the materials of Pancasila as elaborated in the Guidelines for Instilling and Implementing Pancasila. The changes are in line with educational missions as mandated by Peoples' Consultative Assembly Provision No. II/MPR/1978. Pancasila Moral Education was compulsory for primary, junior secondary, senior secondary, teacher education, and vocational schools. The subject continued to be maintained both in its name and content until the implementation of Curriculum 1984, which was basically the refined version of 1975 Curriculum 1975.

The enactment of Law No. 2 of 1989 concerning National Education System that establishes curriculum content of Pancasila Education and Civic Education as compulsory subjects for the curriculum of all levels, paths, and types of education (Article 39) and curriculum of Primary and Secondary Education 1994 has accommodated new educational missions through the introduction of the subject of Pancasila and Civic Education.

In the development of the paradigm of civic education in Indonesia, in 1975/1976, Pancasila Moral Education emerged, whose vision and missions were oriented at the values contained in Pancasila and the 1945 Constitution. The condition remained until the refinement of Curriculum of Pancasila Moral Education 1975/1976 into Curriculum 1984, with the same vision and missions but a new content of the Guidelines for Instilling and Implementing Pancasila or Eka Prasetya Pancakarsa, including the 36 items of Pancasila values. Nonetheless, the vision and missions were still loaded with value inculcation, which was basically an improvisation of unavoidable indoctrination.

With the transformation of Pendidikan Kewargaan Negara/Citizenship Education into Pendidikan Moral Pancasila/Pancasila Moral Education, both in Curriculum 1975/1976 and Curriculum 1984, the development of civic virtue and civic culture in the practice of democracy that should naturally be the identity of Civic Education has transformed accordingly into moral education, which in reality is inexorable from the context of education of goals, values, and democracy concept. The transformation occurred, as is the case with the changes in Curriculum 1968 and Curriculum 1975, among others due to the development of the paradigm in civic education that became the basis and guideline of curriculum development.

The condition in fact continued until the change of Pancasila Moral Education Curriculum 1984 into the Curriculum of Pancasila and Civic Education 1994, which although its name covers Pancasila education and civic education in line with Law No. 2 of 1989, the curricular characteristics were still loaded with the education of moral and Pancasila, dominated by the processes of value inculcation and knowledge dissemination.

The characteristics can be observed in the profile of curriculum of Pancasila and Civic Education (Departmen Pendidikan dan Kebudayaan, 1993) as follow:

- In primary school, Pancasila and Civic Education (PPKn) aims to "Cultivate daily attitudes and behavior based on Pancasila values, both as individuals and community members, and equip students with the abilities to continue their education to junior secondary school" (Departmen Pendidikan dan Kebudayaan, 1993: 1). Meanwhile, in junior secondary school, PPKn intends to "Develop knowledge and capabilities in understanding and appreciating Pancasila values in an attempt of molding the attitude and behavior of a 
responsible individual, member of the society, and citizen; and to equip students with the abilities to continue their education at the secondary level" (Department Pendidikan dan Kebudayaan, 1993: 2). Finally, in senior secondary school, PPKn aims to "Improve knowledge and develop the abilities to understand, appreciate, and believe in Pancasila values as guidelines for behavior and life in the society, nation, and state, so that students will become citizens who are responsible and reliable, and to equip students to continue their education" (Departmen Pendidikan dan Kebudayaan, 1994: 2).

- Teaching and learning materials are developed based on the items of value concepts covered in each of the principles of Pancasila, which are then organized articulately for each semester in each grade and level (primary, junior secondary and senior secondary schools). In that way, the value of each principle in Pancasila will be included in each semester in each grade and at every level with different labels, or similar labels but different descriptions.

- With the close connection of the implementation of articulation principle in organizing teaching materials, and by referring to the value item that is really in detail, the teaching and learning process will be very atomistic with a context that tends to be phenomenalistic. Such a condition is paradoxical to the essence of social and national life, which tends to be with characterized and nuanced holistically. Hence, teaching and learning process puts more emphasis on the acceptance of Pancasila values to be things to memorize instead of a holistic view that is contextual.

In line with the macro change in the paradigm of the constitution of social and national life of Indonesia in accordance with the post-amendment 1945 Constitution, Law No. 20 of 2003 on National Education System has been enacted to substitute Law no. 2 of 1989 concerning the same topic. More specifically related to civic education, in Article 37 of Law of National Education System No. 20 of 2003, it is asserted that the teaching materials for Civic Education must be contained in the curriculum for both primary and secondary schools as well as higher education, and more specifically for higher education, the assertion is consolidated by Article 35, Paragraph (3) of Law of the Republic of Indonesia No. 12 of 2012 on Higher Education.

\section{Discussion}

Each nation and state acknowledges the significance of national character building in an attempt of maintaining and sustaining the existence of a nation-state. In Indonesia, Bung Karno had successfully cultivated the seeds of national characters that thrived in this Republic as proven by the successful struggle of Proclaiming the Independence of the Republic of Indonesia. The efforts of developing citizen character is basically a process of inheriting national values, goals, and objectives contained in the state constitution as well as in the messages from the founding fathers. The goal, as is mandated in the 1945 Constitution, is to realize a citizen who is intelligent, participatory, and responsible in living the national and state life in order to achieve the glory and greatness of the independence (Sapriya, 2008, pp. 208-210).

In line with the statement, Civic Education prepares students to be good citizens who master citizenship knowledge originating from multidisciplinary concepts and theories, who believe and transform the knowledge, and practice the values and truths that become the virtues of national and state life, and who are able to apply citizenship skills (Maftuh \& Sapriya, 2005, p. 319). In addition, Civic Education is an education developing the characteristics of a citizen through the teaching of rules and social and national institutions (Kalidjernih, 2010, p. 130).

Civic Education is also termed citizenship education, which according to Cogan $(1999, \mathrm{p}$. 4), in general refers to "...the kinds of course work taking place within the context of the formalized schooling structure", such as "Civics" in the ninth grade and "Problems of Democracy" in the twelfth grade. In this position, "Civic Education" is treated as "...the foundational course work in school" that is designed to prepare "...young citizens for an active role in their communities in their adult lives". Meanwhile, "Citizenship Education" or "education for citizenship" is viewed as "...the more inclusive term and encompasses both these in-school experiences as well as out-of-school or 'non-formal/informal' learning which takes place in the family, in religious organizations, community organizations, and the mediahelp to shape the personality of the citizens", thesis referred to as "citizenship education" or "education for citizenship". Hence, Cogan (1999, p. 5) concludes that "...education for citizenship is the larger overarching concept here, while civic education is but one part, albeit a very important part, of one's development as a citizen".

In the curriculum, Civic Education according to Winataputra and Budimansyah (2007, p. 126) "is designed as an instructional subject that intends to develop individual potentials to be Indonesian citizens who are noble in morals, intelligent, participative, and responsible". The view reciprocates with that of Dewey (1940), who explains, "Citizenship in a democratic state is not just a condition; it is an office. We, therefore, not only have 
rights, but also responsibilities" (Covaleskie, 1994, p. 8).

According to Winataputra and Budimansyah (2007), Civic Education has become an inherent part of the practical instrument of Indonesia's national education in five positions: First, as a subject in schools. Second, as a course subject in higher education institutions. Third, as one of the disciplines of social sciences in the framework of teacher education program. Fourth, as a political education program packaged in the form of Guidelines for Instilling and Implementing Pancasila or the like that is managed by the Government as a crash program. Fifth, as a conceptual framework in the form of individual's and expert group's thought, developed as the foundation and theoretical framework for civic education in the first, second, third, and fourth positions.

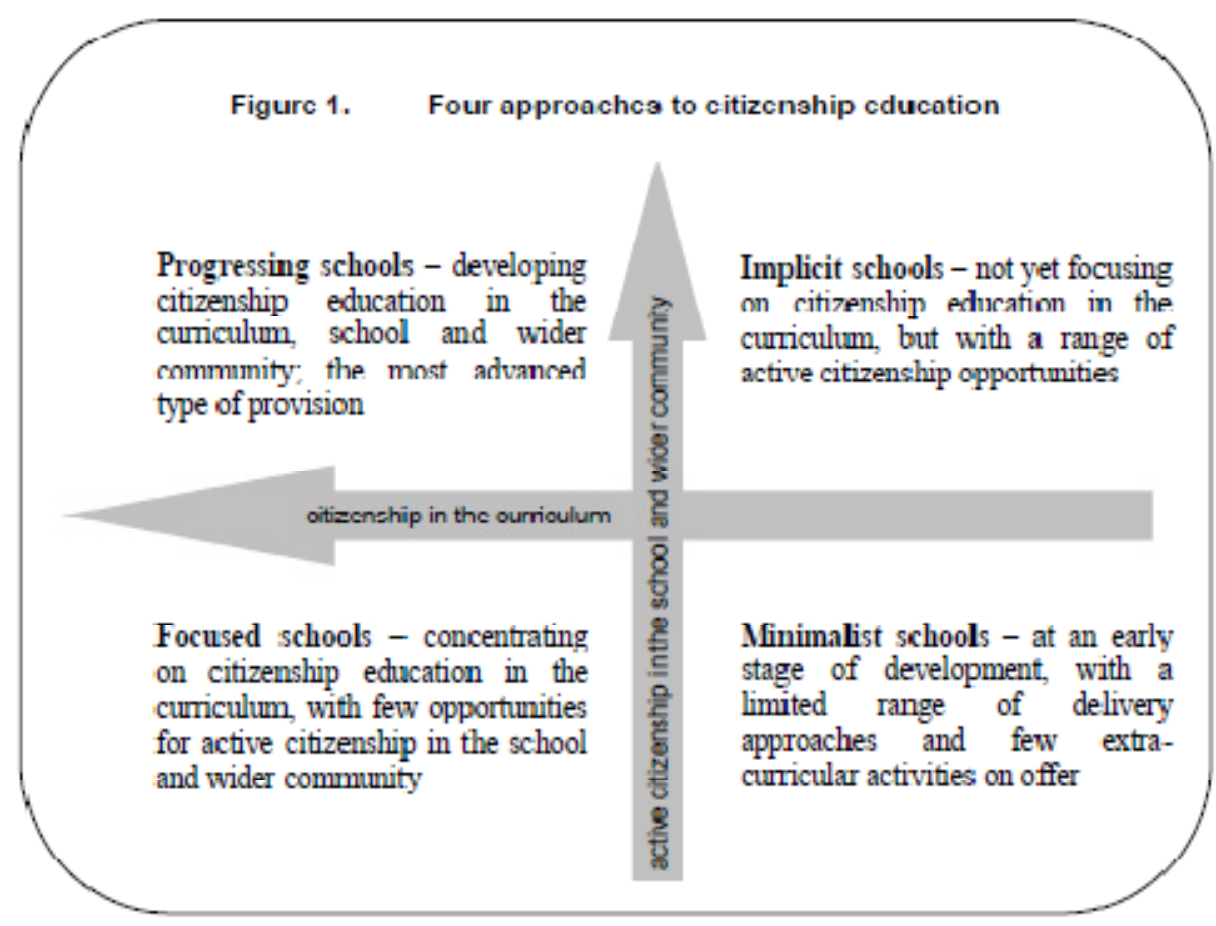

Figure 1. Four approached to citizenship education (Source: Kerr (2005, p.79))

Winataputra and Budimansyah (2007, p. 86) further explain that the configuration or systematic framework of Civic Education is built on the following basic paradigms:

- Curricularly, Civic Education is designed as a learning subject aiming to develop individual potentials to be Indonesian citizens who are noble in morals, intelligent, participative, and responsible.

- Theoretically, Civic Education is designed as a subject that contains the cognitive, affective, and psychomotor dimensions that are confluent or penetrating each other and are integrated in the context of ideas, values, concepts, and morals of Pancasila, democratic citizenship, and national defense.

- Programmatically, Civic Education is designed as a subject stressing on the content embedding values and learning experiences in the form of various behaviors that have to be realized in daily life and are at the same time the demands for citizens in the social, national and state life, as further realization of the ideas, values, concepts, and morals of Pancasila, democratic citizenship, and national defense.

Budimansyah and Suryadi (2008, p. 11) explain that in terms of functions, the subject of Civic Education has three great missions, namely:

- $\quad$ First, conservation education, namely developing and sustaining the noble values of Pancasila

- Second, social and moral development, namely developing and guiding students to be aware of their rights and responsibilities, obedient to the prevailing rules, and well-mannered.

- Third, socio-civic development function, namely developing students in order to understand and become aware of their relationship with other members of the family, school and society, and in the national-state life. 
It is further explained by Budimansyah and Suryadi (2008, p. 68) that "Civic Education is one of the field of studies that carry out the national mission of educating the life of Indonesian people through the corridor of value-based education." Civic Education, in addition to carry the mission of sustaining noble values of Pancasila, has the mission of developing students to understand their rights and responsibilities and be able to position themselves to be good citizens.

Indonesian people are communitarian in nature, believing that a group of people or nation has a number of shared values, not just a collection of individual values (Winarno, 2011, p. 29). In Indonesia, the shared values are the values of Pancasila. Hence, Civic Education has to be oriented at an attempt of understanding one's roles and tasks in the society and implementing the values held to be true by the society. This is in conjunction with Hardee's explanation $(2010$, p. 9) that

Citizenship is not about teaching children how to be obedient but helping them understand their role in society. Their function is not synonymous with "their place" as defined by race, class, or gender. Citizenship is not independent of academic learning outcomes. Children who understand their responsibility in society intrinsically desire proficiency and mastery across the curriculum.

In England, what has become the issue of teaching and learning in schools is character education, as is revealed by Revell and Arthur (2007, p. 80), who disclose, "The introduction of Citizenship Education and changes to the National Curriculum in England have raised the issue of character education as a possible approach to the teaching of moral education in schools". However, there has been no shared understanding of Civic Education and Character Education. On the one hand, Civic Education is thought to be a part of Character Education; on the other hand, Character Education is thought to be a part of Pancasila Education. In England itself, Character Education is a part of Citizenship Education, as pointed out by Revell and Arthur (2007, p. 79), "Whilst character education is seen as part of citizenship education in the school curriculum in England." Nevertheless, Citizenship Education does not have to broaden its concept by developing character, as quoted from Revell and Arthur (2007: 81), "Taken with the goals of the entire National Curriculum and the introduction of Citizenship Education there is an emerging and expanding concept of character development but there is a lack of any fundamental agreement on its justification and content".

According to Winarno (2011, p. 29), Character Education in Indonesia views values as sources and education content as something ideal, important, and has to be developed by the students themselves through the process of intervention and habituation. Such an idea reflects more the moral absolutism rather than moral relativism: "Character education seeks to develop virtue - human excellence - as the foundation of a purposeful, productive, and fulfilling life and a just, compassionate, and flourishing society" (Su, 2008, p. 111). "The phrase "character education' has at least two meanings. In the broad sense, it refers to almost anything that schools might try to provide outside of academics, especially when the purpose is to help children grow into good people" (Kohn, 1997, p. 429). Character education's knowledge focus is more on moral concepts, manners and civility, the citizenship education knowledge base focuses more on politics, government and the interdependencies of social life (Althof \& Berkowtz, 2006, p. 512)

The interconnectedness of Civic Education and character education means (1) Civic Education is defined as education's contribution to the development of characteristics that signify citizens; (2) Civic Education is aimed to realize the formation of a citizen's character that is desired or expected by the nation; (3) Civic Education and character education have one perspective and scope; (4) Civic Education recognizes the needs and attributes and respecting policies, responsibility, fairness, honesty, caring, loyalty, and commitment to democratic ideals; and (5) Civic Education habituates individuals to be more habituated with their participation in the society, nation, and the global world (Machfiroh, 2011, p. 94). In another occasion, it is explained that the link between character and citizenship education is reinforced in other policy documents. However, character and citizenship education share several assumptions about moral education and the role of the school (Revell \& Arthur, 2007, p. 80).

If, indeed, the shared goal of both citizenship education and character education is to foster the development of the kinds of citizens who are both pro-social and effective at participating in a liberal democratic society, then, and only then, can we optimally design schools and school programs that foster good people and good citizens (Althof \& Berkowtz, 2006, p. 513).

There is no special term for "civic education" in the People Republic of China. Civic Education peculiar to China is inherent in moral education. This moral education is always related to the political life in China. In Lee and Ho's (2005, p. 413) observation as well as Bai (1998, p. 525), the term "moral education" (daodejiayou) is also known as ideology education (sixiangjiaou) or political education (zhengzhijiayou) or ideopolitical education, so that the quality of moral is like two sides of a coin, namely the quality of ideomoral and or 
moral-ideopolitical is the same (sixiangzhengzhisuzhi) (Samsuri, 2007, p. 63).

Sapriya (2007, p. 12) mentions at least two quite difficult challenges in the formation of Indonesian communities with character. First, historical challenge, namely the condition of Indonesian people who have the background of colonialism and imperialism. To change the ways of thinking, acting, and behaving of the ancient communities' culture that was feodalistic into the ways of democratic communities is not easy. Second, maintaining and or sustaining the culture of communities and citizens who are learning to live their democratic life so that such a life can be continuously transferred to the next generation.

Critics of the moral dilemma approach argued that values clarification promoted "ethical relativism because it encouraged students to reason through situations that present artificial moral choices and dilemmas" (Lockwood, 1997, p. 74). Former President William Jefferson Clinton, in his 1997 State of the Union Address, emphasized the need for character education as one of the ten central points about education reform (Berkowitz, 1998, p. 1).

Budimansyah (2010, p. 69) reveals that character education in the classroom is implemented in the subject of civic education or other subjects. Specifically for Civic Education that is theoretically designed as a subject containing the dimensions of cognitive, affective, and psychomotor that are confluent in nature or penetrate each other and integrated in terms of ideas, values, concepts, and morals, should necessarily give birth to two impacts simultaneously, namely instructional and accompaniment impacts.

In the mid-1940s, John Dewey advocated moral training and development in the public schools in the context of "community life." Moral education centered upon a conception of school as "a mode of social life, the best and deepest moral training is precisely that which one gets through having to enter into proper relationships with others in a unity of work and thought" (Dewey, 1940, p. 8).

In line with Dewey, Smith says, "Gandhi believed that education, character, and religion should be viewed as exchangeable terms. There is no true education that does not tend to produce character, and no true religion which does not determine character" (1993, p. 147).

Furthermore, Gallien and Jackson assert, "by utilizing African-American perspectives on character issues combined with culturally responsive pedagogy, educators can have a positive impact on character education program in urban areas" (2006, p. 131). Finally, at the highest stage, the child's conscience determines what is right and wrong. Here, respect for individual life and human dignity are guiding principles" (Kohlberg, 1981, p. 53).

\section{Conclusion}

Civic Education is value-based education originating from the crystallization of the value system of the national culture (Pancasila). Civic Education as a subject in schools and a course in higher education institutions can orient students to the acquisition of character, ultimately national character as a country that is united, religious, and humanist.

With the function of Civic Education as a facilitator of national character development and cultivation, it is expected that Indonesian citizens in the future can reflect citizens who are able to practice the national cultural values, namely Pancasila.

The obstacles encountered in the implementation of Civic Education as a medium for national character development are located in the commitment and quality of those who implement it and in the learning methods. This phenomenon signals the need for further studies focused on the implementation and evaluation of policies onthe implementation of Civic Education. It is expected that the implementation of Civic Education in the future will be more effective, so that a strong national character can be developed.

\section{References}

Althof, W., \& Berkow, W. A. (2006). Moral Education and Character Education: Their Relationship and Roles in Citizenship Education. Journal of Moral Education, 35(4), 495-518. http://dx.doi.org/10.1080/03057240601012204

Azra, A. (2001). Pendidikan Akhakdan Budi Pekerti: Membangun Kembali Moral Bangsa. Makalahdalam Buletin Mimbar Pendidikan, UPI Bandung No 1 tahun XXX.

Bai, L. (1998). Monetary Reward Versus the National Ideological Agenda: Career Choice among Chinese

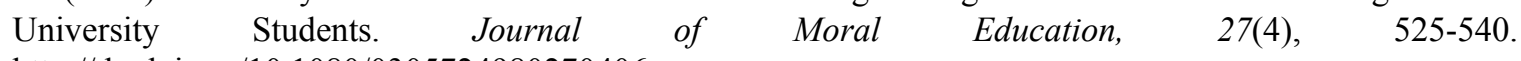
http://dx.doi.org/10.1080/0305724980270406

Berkowitz, M.W. (1998). Educating for character and democracy: A practical introduction. Inucci Morall'd 
articles (pp. 1-14).

Budimansyah, D. (2010). Penguatan Pendidikan Kewarganegaraan Untuk Membangun Karakter Bangsa. Bandung: Widya Aksara Press.

Budimansyah, D., \& Suryadi, K. (2008). Pendidikan Kewarganegaraan dan Masyarakat Multikultural. Bandung: Sekolah Pascasarjana Program Studi Pendidikan Kewarganegaraan Universitas Pendidikan Indonesia, Indonesia.

Cogan, J. J. (1999). Developing the Civic Society: The Role of Civic Education. Bandung: CICED.

Covaleskie, J. F. (1994). Dewey, discipline, and democracy [Electronic version]. Philosophy of Education, 1-8.

Departemen Pendidikan dan Kebudayaan. (1993). Keputusan Menteri Pendidikan dan Kebudayaan Nomor 060/u/1993. Jakarta. Depdikbud.

Departemen Pendidikan dan Kebudayaan. (1994). Kurikulum Sekolah Menengah Atastahun 1994. Jakarta. Depdikbud.

DeRoche, E. F., Sulivan, B. L., \& Garrett, S. D. (1999). Character Matters: Using Newspapers to Teach Character. San Francisco: Use The News.

Desain Induk Pendidikan Karaker Kementerian Pedidikan Nasional Tahun 2010, p. 29 [Grand Design of Character Development, 2010, p. 29]

Dewey, J. (1940). Education Today. New York: Van Rees Press.

Gallien, L. B., \& Jackson, L. (2006). Character Development from African-American Perspectives: Toward a Counternarrative Approach. Journal of Education and Christian Belief, 10(2), 129-142. http://dx.doi.org/10.1177/205699710601000207

Hardee, D. R. (2010). Passionate Pedagogy: Understanding the Impact of Teacher Value and Beliefs on Citizenship/Character Education For Children of Color (Unpublished dissertation). Mills College.

Kalidjernih, F. K. (2010). Kamus Studi Kewarganegaraan Perspektif Sosiologikal Dan Politikal. Bandung: Widya Aksara Press.

Kerr, D. (2005). Citizenship Education in England-Listening o Young People: New Insight from the Citizenship Education Longitudinal Study. International Journal of Citizenship and Teacher Education, 1(1), 74-96.

Kohlberg, L. (1981). Essays on moral development: The psychology of moral development (Vol. II). San Francisco: Harper and Row.

Kohn, A. (1997). How Not To Teach Values: A critical look at character education. Phi Delta Kappan, 78, 428-436.

Lee, W. O., \& Ho, C. H. (2005). Ideopolitical Shifts and Changes in Moral Education Policy in China. Journal of Moral Education, 34(4), 413-431. http://dx.doi.org/10.1080/03057240500410160

Lockwood, A. L. (1997). A letter to character educators. Educational Leadership, 51, $72-75$.

Machfiroh, R. (2011). Revitaslisasi Karakter Bangsa melalui Pendidikan Kewarganegaraan dengan Pengembangan Budaya Lokal. Jurnal Aca Civicus, 4(2), 75-98.

Maftuh, B., \& Sapriya. (2005). Pembelajaran Pendidikan Kewarganegaraan melalui Pemetaan Konsep. Jurnal Civicus, 1(5), 319-328.

McDonnell, G., \& Russell, A. D. (1999). Antiseptics and Disinfectants: Activity, Action, and Resistance.

Revell, L., \& Arthur, J. (2007). Character Education in School and the Education of Teacher. Journal of Moral Education, 36(1), 79-92. http://dx.doi.org/10.1080/03057240701194738

Rohayani, I. (2010). Pengaruh Proses Pembelajaran Pendidikan Kewarganegaraan dan Pendidikan Interventifterhadap Karakter Warga Negara Muda. Jurnal Acta Civicus, 4(1), 1-16.

Sabarudin. (2010). Pengaruh Pembelajaran Konsep Demokrasi Berbasis Sketsa Kewarganegaraan Terhadap Upaya Membangun Karakter Unggul Siswa SMA. Jurnal Acta Civicus, 4(1), 61-82.

Samsuri. (2007). Civic Education Berbasis Pendidikan Moral di Cina. Jurnal Acta Civicus, 1(1), 63-76.

Sapriya. (2007). Kedudukan Pendidikan Kewarganegaraan dalam Konteks Filsafat Pendidikan. Jurnal Civicus, 2(9), 619-625.

Sapriya. (2008). Perspektif Pemikiran Pakartentang Pendidikan Kewarganegaraan dalam Pembangunan Karakter 
Bangsa. Jurnal Acta Civicus, 1(2), 207-223.

Smith, B. D. (1993). Can virtue be taught? South Bend IN: University of Notre Dame Press.

Somantri, M. N. (2001). Menggagas Pembaharuan Pendidikan IPS, Bandung. Penerbit PT Remaja Rosdakarya.

$\mathrm{Su}$, B. (2008). A Comparison and Research on the Sino-US Character Education. Journal of Asian Social Science, 4(10), 111-115.

Suryabrata, S. (1983). Metode Penelitian. Jakarta: CV Rajawali.

Winarno. (2011). Pendidikan Karakter Di Indonesia dalam Perspektif Filsafat Moral dan Filsafat Pendidikan. Jurnal Aca Civicus, 4(2), 1-32.

Winataputra, U. S. (2001). Jatidiri Pendidikan Kewarganegaraan sebagai Waha Sistemik Pendidikan Demokrasi: Suatu Kajian Konseptualdalam Konteks Pendidikan IPS (Unpublished dissertation). Universitas Pendidikan Indonesia.

Winataputra. \& Budimansyah. (2007). Civic Education (Konteks, Landasan, Bahan Ajar dan Kultur Kelas). Bandung: Program Studi Pendidikan Kewarganegaraan SPs UPI.

\section{Notes on Indonesia's Government Policies:}

Undang-Undang Dasar Negara Republik Indonesia tahun 1945.

Ketetapan MPR No.II/MPR/1978 tentang Pedoman Penghayatan dan Pengalaman Pancasila.

Undang-Undang Nomor 12 tahun 2012 tentang Perguruan Tinggi.

Undang-Undang Nomor 20 tahun 2003 tenatng Sistem Pendidikan Nasional.

Undang-Undang Nomor 2 tahun 1989 tentang Pokok-Pokok Sistem Pendidikan Nasional

Peraturan menteri Nomor 22 tahun 2006 tentang Standar Isi.

Peraturan Menteri Nomor 23 tahun 2006 tentang Standar Kompetensi Lulusan.

Peraturan Pemerintah RI Nomor 19 Tahun 2005 tentang Standar Nasional Pendidikan

\section{Copyrights}

Copyright for this article is retained by the author(s), with first publication rights granted to the journal.

This is an open-access article distributed under the terms and conditions of the Creative Commons Attribution license (http://creativecommons.org/licenses/by/3.0/). 